\title{
SYSTEMIC KANAMYCIN TREATMENT HAS NO EFFECT ON CELL NUMBERS IN THE MOUSE UTRICULAR MACULA
}

\author{
Mette KirkegaArd ${ }^{1}$, Stig Å Severinsen ${ }^{2}$, Lise Wogensen $^{3}$ And Jens R NyengaArd ${ }^{2}$ \\ ${ }^{1}$ Center for Hearing and Communication Research, Karolinska University Hospital, Stockholm, Sweden; \\ ${ }^{2}$ Stereology and Electron Microscopy Research Laboratory, University of Aarhus, Denmark; ${ }^{3}$ Research \\ Laboratory of Biochemical Pathology, Institute of Clinical Medicine, Aarhus University Hospital, Denmark \\ e-mail: mette.kirkegaard@cfh.ki.se \\ (Accepted May 24, 2005)
}

\begin{abstract}
The aim of the present study is to estimate the total number of the sensory hair cells (chalice innervated and bouton innervated) and supporting cells in the mouse utricular sensory epithelium at two different time points after systemic kanamycin treatment. Mice were given two daily subcutaneous injections of kanamycin ( 600 or $900 \mathrm{mg} / \mathrm{kg}$ ) for 15 consecutive days and allowed to survive either 1 or 3 weeks after end of treatment. Cell numbers were estimated using a physical fractionator. Paraffin-embedded tissue was immunohistochemically stained for active caspase-3 in order to detect apoptosis. There was no change in hair cell or supporting cell number after treatment with kanamycin and the survival time had no effect. Although no positive staining for caspase-3 was seen, hair cells with swollen chalices and dark stained nuclei were observed in the sensory epithelium of the treated animals, indicating some effect of the treatment. In conclusion, the dosing regime and survival times studied here are not sufficient to induce hair cell loss in the mouse utricle.
\end{abstract}

Keywords: aminoglycoside, hair cell number, physical fractionator, stereology.

\section{INTRODUCTION}

Aminoglycosides are very efficient antibiotics that are used against a variety of infections, but unfortunately, they have a toxic effect on the mechano-receptive hair cells of the inner ear. Several studies have demonstrated that aminoglycosideinduced hair cell death is apoptotic (Forge and $\mathrm{Li}$, 2000; Cunningham et al., 2002; Matsui et al., 2004). The degenerative process is thought to be induced by the formation of reactive oxygen species (Wu et al., 2002) as well as the release of cytochrome c from the mitochondria (Nakagawa and Yamane, 1999), both which leads to caspase activation and apoptosis.

Since proliferative regeneration is limited in the mammalian inner ear (Rubel et al., 1995; Kuntz and Oesterle, 1998) it is important to learn more about the ototoxic effects and how to prevent them. A vast amount of the inner ear research conducted during the past decades has focused on how to minimize the harmful effects of aminoglycosides and how to induce regeneration of hair cells in the damaged sensory epithelia. So far, most experiments have been performed on guinea pigs (Forge et al., 1993, 1998;
Rubel et al., 1995) and chinchilla (Tanyeri et al., 1995; Lopez et al., 1997), since it is difficult to induce damage to the inner ear hair cells of mice using systemic application of aminoglycosides. However, mice are increasingly used in inner ear research due to the availability of different genetic models and hence a reliable ototoxicity model in mice is needed. Such a model was recently demonstrated by $\mathrm{Wu}$ and co-workers (2001), where it was shown that high concentrations of kanamycin induced hearing loss in three different strains of mice. The effect on the vestibular system was evaluated by swimming behaviour, which showed reduced performance in the treated animals. Counting hair bundles on whole mount preparations of utricular maculae showed a loss of hair bundles in maculae from treated animals (Wu et al., 2001). However, it can be speculated whether vestibular hair cells are lethally affected by the kanamycin treatment or the vestibular dysfunction was due to loss of hair bundles only. In order to decide whether hair cells are completely lost, it is necessary to estimate the hair cell number by counting cell nuclei on sections as opposed to counting hair bundles on surface preparations. 
Although very limited, there is some regeneration in the mammalian vestibular sensory epithelia. This is probably due to direct transdifferentiation of supporting cells (Li and Forge, 1997; Forge et al., 1998; Parietti et al., 1998). Hence, it is very important to quantify supporting cell numbers when estimating loss of hair cells.

The purpose of the present study was to evaluate the effect of two different kanamycin concentrations by estimating the total number of the two hair cell types and supporting cells in the utricular macula. Cell numbers were estimated at two different survival times using the physical fractionator. Also, inner ear tissues from kanamycin treated animals were immunohistochemically stained for active caspase-3.

\section{METHODS}

\section{ANIMALS AND DOSING REGIME}

Female albino mice of the strain Balb/cA Bom, 3-4 weeks old were purchased from $M$ \& B Laboratory Animals A/S, Ry, Denmark. The mice were kept in the Animal Facility at the University of Aarhus. They had free access to food and water and were allowed 1 week of acclimation before the start of the experiments. The experiment was approved by the Danish Experimentation Inspectorate.

Kanamycin was administered following a dosing regime described by $\mathrm{Wu}$ et al. (2001). Kanamycin sulfate (Amersham Biosciences, Hørsholm, Denmark) was dissolved in physiological saline and the solutions were corrected for activity, i.e., the concentrations given in the following are the pure kanamycin concentration not including sulfate and water. The mice were injected subcutaneously twice a day for 15 consecutive days and control animals were given corresponding volumes of physiological saline. Mice were given either $2 \times 600$ or $2 \times 900 \mathrm{mg}$ kanamycin $/ \mathrm{kg}$ body weight/day and allowed to survive for 1 or 3 weeks after end of treatment where they were compared to age-matched control groups. This resulted in two control groups and four experimental groups. Animals were weighed twice a week and the injections were adjusted according to weight. After the end of treatment, on day 16 , urine was collected in order to measure creatinine/protein ratio, as an evaluation of kidney function.

\section{FIXATION}

On the day of sacrifice, mice were weighed, anaesthetized with pentobarbital (Mebumal, SAD [Sygehus Apotekerne, Danmark], Denmark; $50 \mathrm{mg} / \mathrm{kg}$, intraperitonally) and blood samples were collected from the left ventricle of the heart. Animals were killed by perfusion through the left ventricle with a solution of $4 \%$ paraformaldehyde and $0.1 \%$ glutaraldehyde in $0.1 \mathrm{M}$ phosphate buffer. The bony labyrinths from one ear (right/left was chosen at random) were postfixed for $3 \mathrm{hrs}$ in $3 \%$ glutaraldehyde in $0.1 \mathrm{M}$ phosphate buffer followed by $1 \mathrm{~h}$ in a solution of $1 \%$ $\mathrm{OsO}_{4}$ in phosphate buffer. Following further dissection, the utricular maculae were dehydrated in a graded series of alcohols and embedded in Epon plastic resin (TAAB 812; TAAB Laboratories Equipment Ltd, Berkshire, England). The labyrinths from the other ear were post-fixed for $3 \mathrm{hrs}$ in the perfusion solution and the utricular maculae were isolated and embedded in paraffin.

\section{STEREOLOGY}

For stereological analysis, the Epon embedded maculae were cut in $2 \mu \mathrm{m}$ sections, approximately at a right angle to the surface, stained with toluidine blue $(0.1 \%)$ and cover slipped. The section sampling fraction (SSF) was $1 / 30$, which produced between 6 and 8 samples per macula (see Fig. 1 for details). Estimation of cell numbers was performed using a modified Olympus BX50 microscope. Systematic uniformly random sampling of field of views was performed using a motorized specimen stage (Merzhauser, Germany) which enabled the movements in the $\mathrm{x}$ and $\mathrm{y}$ axes to be controlled. A CCD camcorder (JVC, KY-F 50E, Japan) connected to a Dell PC was mounted on the top of the microscope. The computer fitted with a framegrabber (flashpoint 3D PRO, USA) was connected to a 21" monitor (EIZO 120-FlexScan, USA) and had the CAST stereology software (ver. 2, Visiopharm, Denmark) installed, allowing 2D counting frames to be superimposed on the images. The sections were viewed with a $40 \times$ objective $(\mathrm{NA}=0.75)$. 
I
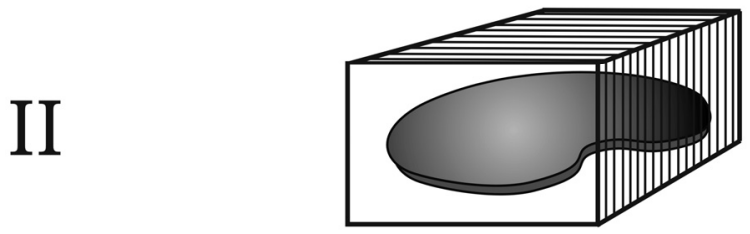

III
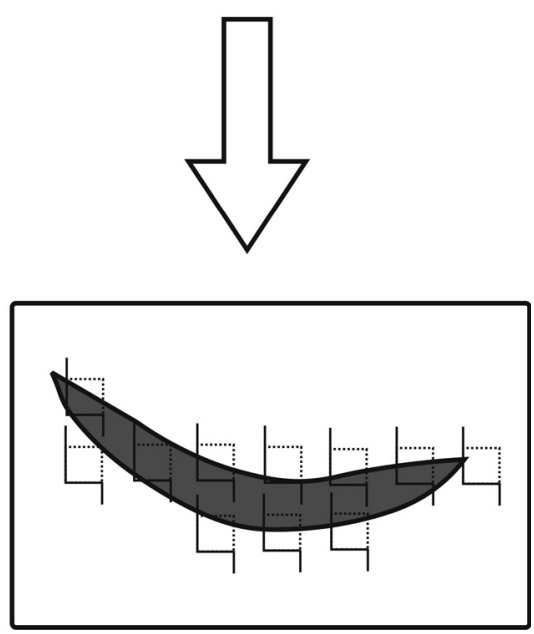

Fig. 1. Sampling design. The kidney-shaped sensory epithelium was randomly oriented around the vertical axis (I) and embedded. The embedded tissue was cut in sections and every $30^{\text {th }}$ section was sampled (section sampling fraction $=1 / 30 ;$ II). On each of the sampled sections, systematic uniformly random sampling of fields of view was performed (III).

Cell nuclei were counted using a physical disector (Sterio, 1984). Round to oval nuclei situated in the upper $2 / 3$ of the sensory epithelium was counted as hair cells. Dark, irregular nuclei situated close to the basal lamina (lower third of the sensory epithelium) were counted as supporting cells. Hair cells where discerned by their innervation. Chalice innervated hair cells are completely embraced by the afferent nerve ending (chalice), and bouton innervated hair cells have no visible chalice (the afferent and efferent nerves are not visible in all sections). In practice, counting was performed using a "splitscreen" disector, a feature of the software CAST 2 where the sampling section and the look-up section could be observed simultaneously (Fig. 2).

According to the fractionator principle (Gundersen, 1986), the total number of each cell type, N(cell), could be estimated as:

$$
\begin{aligned}
N(\text { cell }) & :=\frac{1}{S S F} \times \frac{1}{A S F} \times \frac{\Sigma \mathrm{Q}^{-}(\text {cell })}{2} \\
& =30 \times \frac{a(\text { frame })}{d x \times d y} \times \frac{\Sigma \mathrm{Q}^{-}(\text {cell })}{2}
\end{aligned}
$$

where $\Sigma \mathrm{Q}^{-}$(cell) was the total number of the specific cell type counted in the sample, divided by 2 because the counting was performed both ways. The section sampling fraction, SSF, was $1 / 30$ and the area sampling fraction, ASF, equaled the stepping distance in both $\mathrm{x}$ and $\mathrm{y}$ direction divided by the area of the frame, a(frame). In this particular case, the area of the frame and the stepping distances were chosen in order to sample the entire sensory epithelium on the section $(\mathrm{a}($ frame $)=\mathrm{dx} \cdot \mathrm{dy})$, hence the total number of each cell type could be estimated as:

$$
N(\text { cell }):=15 \times \Sigma \mathrm{Q}^{-}(\text {cell })
$$

\section{QUALITATIVE EVALUATION}

In each utricle, a central light microscopical section was qualitatively evaluated blindly by a scoring system. A section was given the value 0 if the morphology of the sensory epithelium appeared normal, 1 if the sensory epithelium appeared normal, but one or two hair cells were darkly stained, 2 if three or more of the hair cells in the section appeared dark and swollen nerve chalices were present. A section was given the value 3 if there were many dark stained hair cells and swollen chalices. Swollen nerve chalices and condensed, marginated chromatin resulting in darkly stained nuclei are some of the initial signs of aminoglycoside toxicity in hair cells (Forge and Schacht, 2000). 

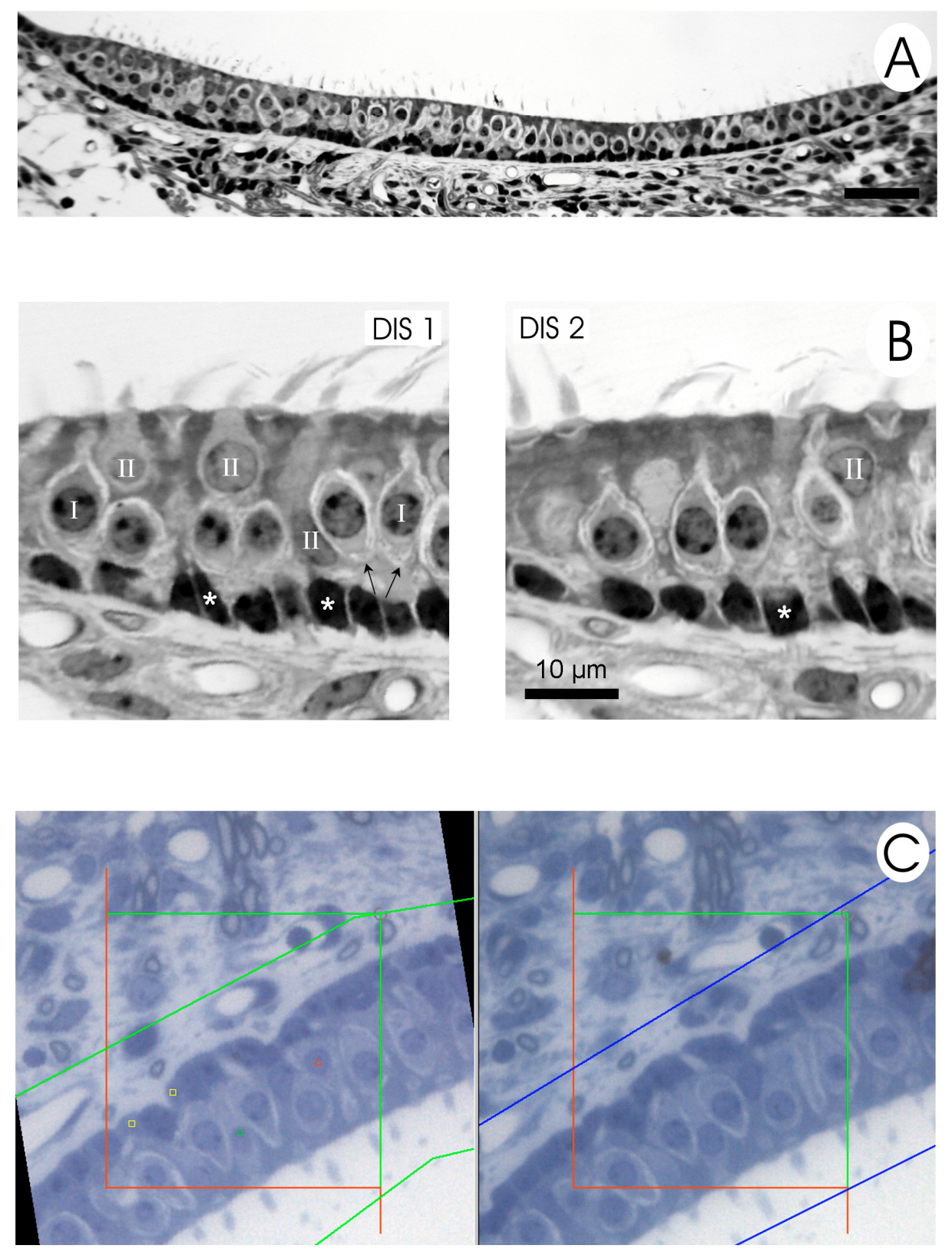

Fig. 2. A: cross section of the utricular macula demonstrating the general appearance of the sensory epithelium. The sensory hair cells are situated in the upper part of the sensory epithelium and their hair bundles are seen at the surface. The supporting cell nuclei are situated close to the basal lamina. See fig $2 B$ for details. Scale bar: $40 \mu \mathrm{m}$. B: The physical disector. Type I and type II hair cells are discerned by the presencelabsence of a chalice. The nerve chalice is recognized as a light staining band surrounding the cell body. The chalices of two type I hair cells are pointed out by arrows in disector 1 (DIS 1). Cells are counted when present in the sampling section, but not in the look-up section. If DIS1 is used as sampling section and DIS 2 as look-up section, seven cells are counted: two supporting cells (marked with *), two type I hair cells (marked with I) and three type II hair cells (marked with II). When DIS 2 is used as sampling section, two cells are counted (one supporting cell and one type II hair cell). C: Demonstration of the "split screen" feature of the software CAST 2. An image of the sampling section (left) is compared to a live image of the look-up section. An unbiased counting frame is superimposed on the images. 


\section{IMMUNOHISTOCHEMISTRY}

The paraffin embedded maculae were sectioned and used for immunohistochemical staining for active caspase-3. Sections were deparaffinized, rehydrated and blocked with $0.02 \mathrm{M}$ glycine. The epitopes were demasked by $0.25 \%$ trypsin for $10 \mathrm{~min}$ at room temperature. After blockage with 2\% normal serum, primary antibody against active caspase-3 was added (1:250 and 1:300, R\&D Systems, UK). Thereafter sections were incubated with biotin labeled secondary antibody (1:200, Vector Laboratories, CA. USA) that was detected by the $\mathrm{ABC}$ kit (Vetor Laboratories, CA, USA) and 3,3 diaminobenzidine, (Sigma-Aldrich, Mi, USA). Sections were dehydrated and mounted. Mice ovaries served as positive controls for the caspase-3 staining.

\section{PLASMA AND URINE CREATININE}

In order to monitor kidney function of the animals, creatinine/protein ratio in the urine was measured using a colorimetric assay for measuring protein concentration (Bio-Rad Protein Assay). Plasma creatinine was measured enzymatically using a Vitros 950 system from Ortho-Clinical Diagnostics (Copenhagen, Denmark) at department of Clinical Biochemistry, Aarhus University Hospital at Skejby.

\section{STATISTICS}

The estimated cell numbers were compared by two way analysis of variances (SigmaStat, ver. 2.0, SPSS Inc.). In the graphs, results are given as individual estimates and mean for each group and in the text, as Mean (CV) [min; max]. The total variation $\left(\mathrm{CV}_{\text {total }}\right)$ and the coefficient of error of the method $\left(\mathrm{CV}_{\mathrm{met}}\right)$ were calculated for each cell number estimate. The coefficient of variation was calculated as $\mathrm{SD} /$ mean and the coefficient of error was calculated by equations from Gundersen et al. (1999). From these, the biological variation $\left(\mathrm{CV}_{\text {bio }}\right)$ was calculated $\left(\mathrm{CV}_{\text {bio }}=\sqrt{\mathrm{CV}_{\text {total }}^{2}-\mathrm{CV}_{\text {met }}^{2}}\right)$. Estimates of $\mathrm{CV}_{\text {total }}$ and $\mathrm{CE}_{\text {met }}$ and calculated $\mathrm{CV}_{\text {bio }}$ are shown in Table 1. Considering the differences we want to detect between groups and the desired power of the test we consider the CE's to be within acceptable limits (see also Cruz-Orive et al., 2004).

There was no statistical significant difference between the two control groups (1 and 3 weeks survival) and to make the graph simpler, they are shown together as "control".
Table 1. Coefficient of variation $\left(C V_{\text {total }}\right)$ and coefficient of error $\left(C E_{\text {met }}\right)$.

\begin{tabular}{lccc}
\hline & $\mathrm{CV}_{\text {total }}$ & $\mathrm{CE}_{\text {met }}$ & $\mathrm{CV}_{\text {bio }}{ }^{\mathrm{a}}$ \\
\hline $\mathrm{N}(\mathrm{HCI})^{\mathrm{b}}$ & 0.120 & 0.086 & 0.084 \\
$\mathrm{~N}(\mathrm{HCII})$ & 0.160 & 0.125 & 0.100 \\
$\mathrm{~N}(\mathrm{SC})$ & 0.230 & 0.103 & 0.206 \\
\hline
\end{tabular}

${ }^{a}$ The biological variation is calculated from $C V_{\text {total }}$ (see methods); ${ }^{\mathrm{N}} \mathrm{N}(\mathrm{HCI})$ : number of type I hair cells; $\mathrm{N}(\mathrm{HCII})$ : number of type II hair cells; $\mathrm{N}(\mathrm{SC})$ : number of supporting cells.

\section{RESULTS}

There was no difference in plasma creatinine content between control animals and the animals treated with $2 \times 600$ or $2 \times 900 \mathrm{mg} / \mathrm{kg}$ kanamycin and the urine creatinine/protein ratio was within normal limits for all animals. Both control and kanamycin treated animals increased in weight during the experimental period (Fig. 3). The mean weight of all animals increased from $17.7 \mathrm{~g}(0.08)[15.2 ; 20.8]$ at the beginning of the experiment to $21.0 \mathrm{~g}(0.05)$ $[19.4 ; 22.1]$ at two weeks after end of treatment.

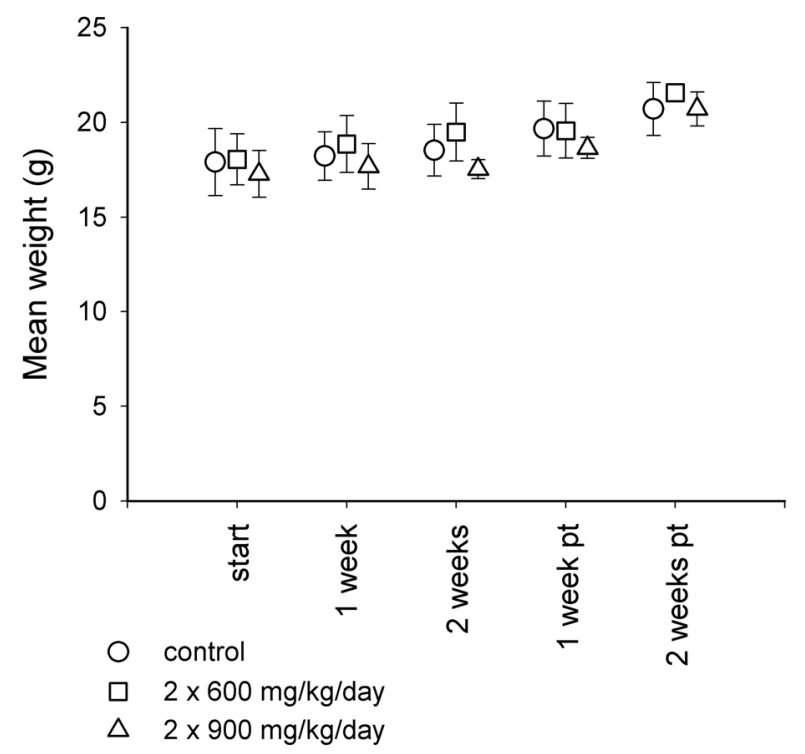

Fig. 3. Weight shown as mean $\pm S D$ for control animals and kanamycin-treated animals. Animals were weighed before the kanamycin treatment (start) and twice every week, but only the mean weight for each week is shown. $N=8$ for each bar at each time point except for 2 weeks post treatment (pt), where only the 3-weeks-survival animals are included $(n=$ 4). 


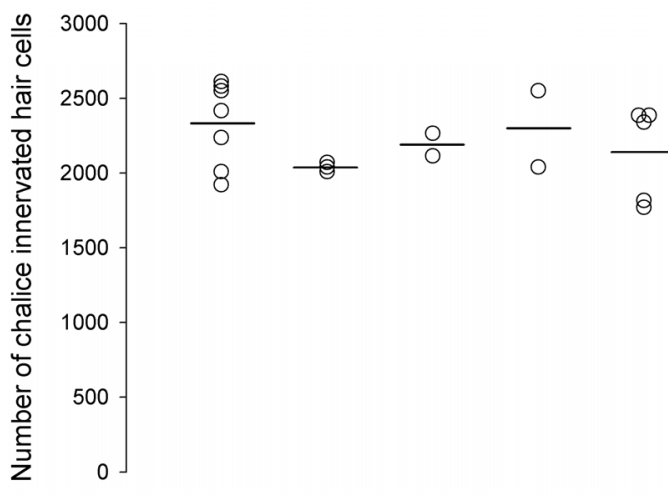

A

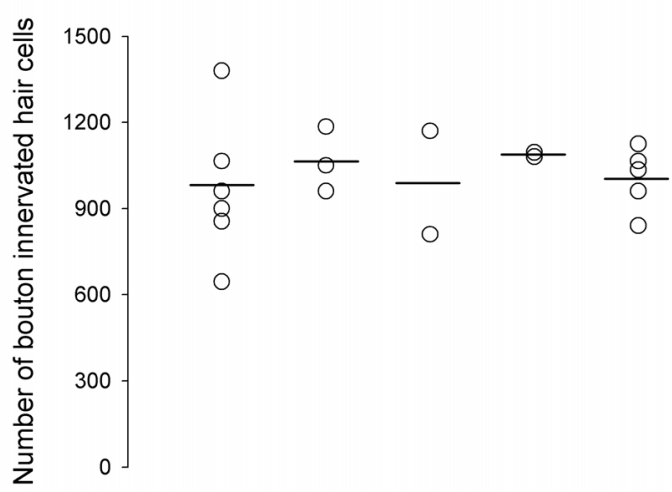

B

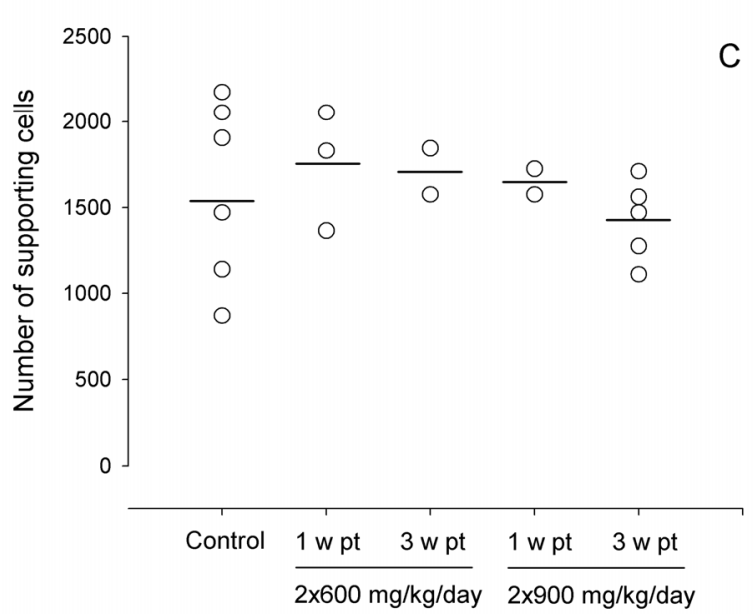

Fig. 4. Cell numbers shown as individual estimates (open circles) and mean for each group (horizontal bar). A: The number of chalice innervated hair cells. B: The number of bouton innervated hair cells. $\boldsymbol{C}$ : The number of supporting cells. Control represents both control groups (1 and 3 weeks survival after end of treatment).

The number of chalice innervated hair cells did not differ between control animals and animals treated with $2 \times 600 \mathrm{mg}$ kanamycin/kg/day or $2 \times 900 \mathrm{mg}$ kanamycin/kg/day $(2 \mathrm{p}=0.47$; Fig. $4 \mathrm{~A})$ and there was no effect of survival time $(2 p=0.85)$. The mean number of chalice innervated hair cells for all groups was 2214 (0.12)[1770; 2610]. Likewise, there was found no difference in the number of bouton innervated hair cells between the control group and the two treatment groups $(2 \mathrm{p}=0.73)$. Survival time had no effect $(2 \mathrm{p}=0.42)$. Mean number of bouton innervated hair cells for all groups was 1012 (0.16) [645; 1380] (Fig. 4B). The number of supporting cells (Fig. 3C) did not change with treatment $(2 \mathrm{p}=$ $0.20)$ or time $(2 \mathrm{p}=0.09)$. The mean number of supporting cells in all groups was $1571(0.23)$ [870; 2175].

In order to further evaluate the condition of the sensory epithelium, one light microscopical section from each utricle was evaluated blindly by a scoring system (see methods). The qualitative evaluation resulted in an average score of 0.14 for maculae from control mice, 0.17 for maculae from mice that received $2 \times 600 \mathrm{mg}$ kanamycin $/ \mathrm{kg} /$ day and survived 1 week and 1.5 for maculae from mice that received $2 \times 600 \mathrm{mg}$ kanamycin/ $\mathrm{kg} /$ day and survived 3 weeks. Mice that received $2 \times 900 \mathrm{mg}$ kanamycin $/ \mathrm{kg} / \mathrm{day}$ had an average score of 1 and 1.5 for the 1 and 3 week survival group, respectively.
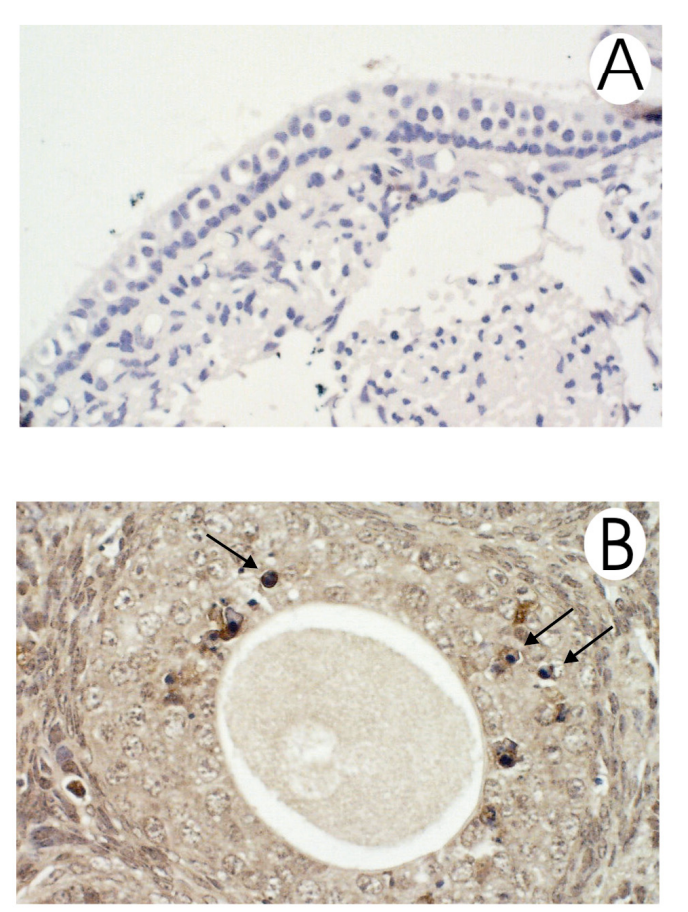

Fig. 5. Immunohistochemical staining for active caspase-3. A: Utricular macula treated with $2 \times 900$ mg kanamycin $/ \mathrm{kg} /$ day. No positive staining for caspase-3. B: Mouse ovary served as positive control. Several follicle cells stain for caspase-3 (arrows). Original magnification: $\times 100$ 
In order to determine if the affected cells were apoptotic, paraffin-embedded maculae from kanamycintreated mice were immuno-histochemically stained with antibody against active caspase-3. The staining showed no specific caspase-3 staining while the positive controls (mouse ovaries) showed distinct staining of the follicle cells (Fig. 5).

\section{DISCUSSION}

The present study has estimated total cell number, including supporting cells, chalice and bouton innervated hair cells in utricles from control and kanamycin treated Balb/cA mice. Analysis of urine and plasma indicated that kidney function was not detectably affected by the kanamycin treatment and the mean weight of the animals demonstrates that all animals were in good health.

There was no change in hair cell or supporting cell numbers in the mouse utricular macula after in vivo treatment with kanamycin. However, the maculae from the treated mice did receive a higher score than the ones from control animals at the blinded evaluation of the sensory epithelium. This was due to the observation of hair cells with swollen nerve chalices and darkly stained nuclei and indicates that the sensory epithelium is somewhat affected by the kanamycin dosing regime used. This corresponds with the results of behavioral tests performed previously (Wu et al., 2001). Attempts to label the kanamycin treated utricles embedded in paraffin with a caspase-3 antibody failed and thus apoptotic cell death can not be confirmed at this point. Hence, the affected hair cells observed in the present study are probably not apoptotic, but could be dying through a slower process of degeneration, i.e., necrosis. Alternatively, the dark stained cells and swollen nerve chalices in the kanamycin-treated utricles represent cells that are sub-lethally damaged and that eventually will recover. Recovery after aminoglycoside treatment has previously been observed in in vitro cultures of rat utricles (Zheng et al., 1999).

The affected hair cells observed are all chalice innervated hair cells, which confirms that these cells are more sensitive to aminoglycosides than the bouton innervated hair cells as shown in a previous study of the chinchilla cristae (Lopez et al., 1997). Despite the occasionally observations of affected hair cells in the kanamycin-treated animals, it must be concluded that this dosing regime does not significantly reduce hair cell number in the utricular macula of the mouse within the time period studied. It is possible that longer survival time would affect the hair cell number.

The intention of the present investigation was to perform a quantitative evaluation of the aminoglycoside ototoxicity model introduced by $\mathrm{Wu}$ et al. (2001). However, this dosing regime does not significantly reduce the number of hair cells in the utricular macula and no apoptotic cells could be identified. In the study by $\mathrm{Wu}$ et al. (2001), a reduced number of hair bundles (the hair cells apical protrusions) was observed in surface preparations which can explain the reduced performance in the behavioral tests. Loss of the apical hair bundle does not necessarily mean that hair cells are lost. It has been shown that utricular hair cells treated with gentamicin, lose the hair bundle but survive and regrow a new bundle (Zheng et al., 1999). This emphasizes the importance of counting the cell bodies and not only the apical hair bundle when estimating hair cell numbers.

One explanation for the constant hair cell number in the utricles of kanamycin-treated mice is that only the striolar hair cells are affected by the kanamycin treatment. The striolar hair cells comprise about $10 \%$ of the total hair cell population and a change within that range would not be detected with the method used here (the calculated CE's are 0.086 and 0.125 for chalice and bouton innervated hair cells respectively; Table 1). Alternatively, one could argue that lost hair cells have been replaced by supporting cells, but it is doubtful that this could happen within the time period studied, and no change in supporting cell numbers was observed

Although no change in hair cell number was detectable within the time period studied, it is possible that cell size could be affected by the treatment. It has been shown previously that cell volume is a very sensitive pathological parameter and that changes in cell volume are detectable before changes in cell number (Tandrup and Brændgaard, 1994). This is why the remaining analyses will include estimations of volume and volume density of hair cells which will be estimated on thin sections using electron microscopy.

The present study introduces a promising technique for evaluating hair cell loss in the utricular macula on light microscopical sections, but indicates that the mouse utricle is not a suitable model for studies of hair cell death after systemic treatment with kanamycin. Recently, two alternative methods for inducing aminoglycoside ototoxicity in the mouse inner ear were introduced (Heydt et al., 2004; 
Nakagawa et al., 2003). Both methods use local application of aminoglycoside and demonstrate that this might be the only way to obtain a local concentration of aminoglycoside high enough to induce reliable, dose-dependent ototoxicity.

\section{ACKNOWLEDGEMENTS}

Jan Møller at Aarhus University hospital, Skejby, kindly provided the data on plasma creatinine. We appreciate the expert assistance of Herdis Krunderup in embedding, sectioning and staining the maculae. This study was supported by the Oticon Foundation.

\section{REFERENCES}

Cruz-Orive LM, Insausti A, Insausti R, Crespo D (2004). A case study from Neuroscience involving Stereology and Multivariate Analysis. In: Evans SM, Janson AM, Nyengaard JR, eds. Quantitative Methods in Neuroscience. Chapter 2. Oxford: Practical Neuroscience Series, Oxford University Press, 16-64.

Cunningham LL, Cheng AG, Rubel EW (2002). Caspase activation in hair cells of the mouse utricle exposed to neomycin. J Neurosci 22:8532-40.

Forge A, Li L, Corwin JT, Nevill G (1993). Ultrastructural evidence for hair cell regeneration in the mammalian inner ear. Science 259:1616-9.

Forge A, Li L, Nevill G (1998). Hair cell recovery in the vestibular sensory epithelia of mature guinea pigs. J Comp Neurol 397:69-88.

Forge A, Li L (2000). Apoptotic death of hair cells in mammalian vestibular sensory epithelia. Hear Res 139: 97-115.

Forge A, Schacht J (2000). Aminoglycoside antibiotics. Audiol Neurootol 5:3-22.

Gundersen HJ (1986). Stereology of arbitrary particles. A review of unbiased number and size estimators and the presentation of some new ones, in memory of William R. Thompson. J Microsc 143(1):3-45.

Gundersen HJ, Jensen EB, Kieu K, Nielsen J (1999). The efficiency of systematic sampling in stereology reconsidered. J Microsc 193:199-211.

Heydt JL, Cunningham LL, Rubel EW, Coltrera MD (2004). Round window gentamicin application: an inner ear hair cell damage protocol for the mouse. Hear Res 192:65-74.

Kuntz AL, Oesterle EC (1998). Transforming growth factor alpha with insulin stimulates cell proliferation in vivo in adult rat vestibular sensory epithelium. J Comp Neurol 399:413-23.

Li L, Forge A (1997). Morphological evidence for supporting cell to hair cell conversion in the mammalian utricular macula. Int J Dev Neurosci 15: 433-46.

Lopez I, Honrubia V, Lee SC, Schoeman G, Beykirch K (1997). Quantification of the process of hair cell loss and recovery in the chinchilla crista ampullaris after gentamicin treatment. Int J Dev Neurosci 15:447-61.

Matsui JI, Gale JE, Warchol ME (2004). Critical signaling events during the aminoglycoside-induced death of sensory hair cells in vitro. J Neurobiol 61:250-66.

Nakagawa T, Yamane H (1999). Cytochrome c redistribution in apoptosis of guinea pig vestibular hair cells. Brain Res 847:357-9.

Nakagawa T, Kim TS, Murai N, Endo T, Iguchi F, Tateya I, et al. (2003). A novel technique for inducing local inner ear damage. Hear Res 176:122-7.

Parietti C, Vago P, Humbert G, Lenoir M (1998). Attempt at hair cell neodifferentiation in developing and adult amikacin intoxicated rat cochleae. Brain Res 813:5766.

Rubel EW, Dew LA, Roberson DW (1995). Mammalian vestibular hair cell regeneration. Science 267:701-7.

Sterio DC (1984) The unbiased estimation of number and sizes of arbitrary particles using the disector. J Microsc 134(2):127-36.

Tandrup T, Brændgaard H (1994). Number and volume of rat dorsal root ganglion cells in acrylamide intoxication. J Neurocytol 23:242-8.

Tanyeri H, Lopez I, Honrubia V (1995). Histological evidence for hair cell regeneration after ototoxic cell destruction with local application of gentamicin in the chinchilla crista ampullaris. Hear Res 89:194-202.

Wu WJ, Sha SH, McLaren JD, Kawamoto K, Raphael Y, Schacht J (2001). Aminoglycoside ototoxicity in adult CBA, C57BL and BALB mice and the SpragueDawley rat. Hear Res 158:165-78.

Wu WJ, Sha SH, Schacht J (2002). Recent advances in understanding aminoglycoside ototoxicity and its prevention. Audiol Neurootol 7:171-4.

Zheng JL, Keller G, Gao WQ (1999). Immunocytochemical and morphological evidence for intracellular self- repair as an important contributor to mammalian hair cell recovery. J Neurosci 19:2161-70. 